\title{
Integrative Transcendental Planning Discourse at Tondok Sillanan in Tana Toraja
}

\author{
IMAM INDRATNO \\ Lecturer Departement of Regional and City Planning, \\ Faculty Engineering of Bandung Islamic University, Bandung, Indonesia \\ email: akudandiriku1@gmail.com
}

\begin{abstract}
Positivism and rationalism are paradigms used in current planning. Therefore, planners have always considered a rational and physical evidence in the planning process. On the other hand, eastern paradigm looks different in the reality. Reality is seen as something holistic. This paper discusses the discourse of the integrative transcendental planning. The research was conducted by the transcendental phenomenological approach to the traditional settlements. The scope of this study is basically still in the context of planning perspective by taking a case study at Tondok Sillanan in Tana Toraja, South Sulawesi. This research explored two main concepts on the traditional settlement, there are madoang (love to the ancestors) and toma'rapu (union). The concept showed that source of planning is not only the senses but also planner's intuition. Reality must be seen from the personal and communal consciousness of society. Finally, the integrative transcendental of planning emphasizes the transcendental consciousness as the spirit of planning.
\end{abstract}

Keyword: Integrative Transcendental Planning, Phenomenology, Transcendental Consciousness

\section{Introduction}

In the area of planning, utopianism paradigm appeared along with the response to the industrial revolution, which was neglecting the space aspects (environment). This paradigm stimulated the idea about the Garden City by Ebenezer Howard in 1898 (Sudaryono, 2012). Further, the theory of planning developed based on positivism paradigm which was signed by the appearance of procedural planning from Faludi in 1973 and the idea of comprehensive planning from Beauregard in 1984 (Campbell, S. 1996). As the theory of communicative action of Habermas was developing in 1984, the planning paradigm began to shift from positivism towards the criticism which was more emphasizing to the communication process, cooperation, as well as a learning process of the planning actors. Type of planning based on the criticism paradigm was developed by Friedman (1987), Innes (1994), Sager (1994), Healey (1997), and Forester (1989).

In the last two decades, the planning was inspired by two developing paradigms namely the postmodernism and phenomenology paradigms. The view of postmodernism realm had generated several views starting from Beaugerard (Campbell, S. 1996) followed by Allmendinger (2001) and Innes (1994). Postmodernism paradigm oriented the planning towards the considerations of cultural diversity as well as the local knowledge of the planning subjects, while the phenomenology paradigm stressed on the gap between the subject and object of planning. Husserl epistemologically attempted to demonstrate the importance of world which is understood through the concept of evidence (presence). Presence is obtained from the consciousness of the thought object. By using the phenomenology approach, the research was conducted to see the transformation phenomena of civilization within the Toraja culture.

The Toraja civilization had been transforming since the entering of the Bible missionary A.A. van Loosdrecht from the GZB (Gereformeerde Zendingsbond) on 10th November 1913 to Toraja. The

Received: December 29, 2017, Revision: March 12, 2018, Accepted: June 29, 2018

Print ISSN: 0215-8175; Online ISSN: 2303-2499. DOI: http://dx.doi.org/10.29313/mimbar.v34i1.3332.246-254

Accredited B based on the decree No.040/P/2014, valid on February, 18, 2014 until February, 18, 2019. Indexed by DOAJ, Sinta, IPI 
GZB movement, influencing the civilization transformation, was separating the aluk (sacred) and ada' (profane) in Toraja society's way of life. After the separation of these two things, the aggregation of Christianity theology started and ada' was filled up in order not to fall into bidaah (Bigalke,2005). This movement had pulled out the basic value of the Toraja society, which was considered as a failure by some observer. The result of Toraya Kombongan 2012 revealed a clear conclusion that The Toraja had been pulled out from the roots of their tradition and religiosity. The Toraja values of culture which are rooted to aluk were put away especially for a ritual procession, the rambu tuka'. Disharmony in some area of life occurred paralleled along with the appearance of pragmatism and hedonism particularly in mantumu ritual.

The transformation process of Toraja culture is manifested in the rambu solo' and rambu tuka' ritual. However, the tongkonan as the main symbol of Toraja culture remained unchanged. The main object of the research was traditional Toraja settlement called tongkonan. Tongkonan meant in this research was a traditional house as a symbol of one blood, one bone of one community. The meaning of tongkonan is not merely physical but more to the social unity within one community.

The focus of the research was not on the tongkonan as the architecture of Toraja, but rather as a main component of a residential system called tondok. The research was conducted in macro and mesoscale. In macro scale, it focused on the administration area of Lembang Sillanan, while in mesoscale it focused on the area of Tangnga Tondok. Several phenomena observed at Tangnga Tondok Sillanan were the layout of Tongkonan community settlement which crowded into one special location, the structure of traditional governance which was not lead by puang, the existence of TangngaTondok that was steadily degraded, and the ritual activity of society is more stressing on the symbol.

\section{Research Methodology}

The objective of this research was to find local theory about the components constructing the layout of the settlement (tondok) at Lembang Sillanan, Tana Toraja Regency. That theory is expected to answer two research questions of: first, what phenomena could be discovered from Toraja culture at Lembang Sillanan? Second, what kind of transcendental consciousness exist in the society related to the tongkonan as the main symbol of Toraja culture at Lembang Sillanan?

This research use phenomenology transcendental approach. Phenomenology is a science/knowledge which is developed without any presupposition, where the knowledge is gained by intuition. In the phenomenology philosophy of Husserl, there is a concept of Evidenz. Evidenz is a presence concept, which is direct, certain, and absolute up to the condition where there is no doubt in it. Based on this, the intuition becomes important to be developed in the phenomenology method. In the logical investigation of Findlay (1970), Husserl explained that epoche (bracketing) is a phenomenology description process from the first person view to ensure that every item is precisely described like it was experienced or meant by the subject. This action must not be dependent on the truth of every existence assumption about an action object and focusing on the intentional action. Hereby, epoche becomes a process of delaying assumption to generate consciousness essence of an intentional action. Husserl was very interested in discovering the shape, value, meaning, and nature. Methodologically, phenomenology is used to explain things about themselves, to know what comes in before consciousness, and to understand the meaning and essence within intuition and self-reflection.

The consequence of the epoche concept in phenomenology is that the study of consciousness is not sufficient to be cogito, but must be cogitations and cogitate. Cogitationes is relating to the thought object while cogitate relating to the consciousness object. Besides, in the phenomenology relating the observed period of time, it is known as the retention and pretention. Retention is observing the time period horizontally to the past. Pretention, on the contrary, is observing to the future as hope and anticipations. Moustakas (1994) and Adian (2010) explained some important concepts related to Husserl phenomenology, namely:1) Consciousness Intentionality. Intentionality is always relating to consciousness. Consciousness is an internal process in human relating to a certain object (real, manifested or not); (2) Noema and Noesis. Noesis (cogitations) means consciousness, while noema (cogitate) means what to be conscious about. Noema and noesis according to Husserl form the structure of consciousness. These distinguish 
the consciousness feature, which is important to the individual object (real or imaginary) before us in the consciousness (noema), and explain how the certainty in the object (real or imaginary ) can be gained, how to experience (action), what to be experienced (noesis); (3) Reduction. The reduction is done to lower the accidental phenomena of the research object, comprising eidetic, phenomenological, and transcendental reductions. Eidetic reduction is aimed to unfold the nature or basic structure of the object (eidos) of a pure or purified phenomenon. Phenomenological reduction is pointed to the subject so that only selfconsciousness will be left. This type of reduction is to protect all possible supposition of the subject about the object and determine its essence. In the transcendental reduction, the delay is not limited to the supposition about the object, but also to the entire existing and reality. The expected result is the appearance of self-consciousness, the activities, namely those which contribute transcendental meaning to an integral part in the consciousness; (4) Intuition. Husserl thought that every human is a creature and able to think intuitively. All things become clear through the intuitive reflective process, namely transformation from what is seen into what appears in the consciousness. Intuition is a presence process (evident) of phenomena essence in the consciousness, meaning that the presence of observed world or certain objects in the phenomenological approach needs to involve intuition; (5) Intersubjectivity. Husserl believed that intuitive reflective process occurred due to ego and superego factors. He did not refuse the intersubjectivity factor which plays a great role in forming the meaning. Although Husserl admitted the importance of transcendental ego in unfolding the meaning and essence, he did not ignore the importance of intersubjectivity, mainly those relating to self-insight and subjective perception from what is real.

\section{Tongkonan as Symbol of Culture}

Tongkonan was derived from the word "tongkon", meaning to the seat. Toraja community themselves interpret tongkonan as "house, given with function, task, and engagement", or an institutional system in the family. Kobong (2008) explained that tongkonan is not merely a big family house or traditional house, but can be functioned as a place to discuss or conduct civil affair as well as to maintain the union of the relatives. Setriyanto (2013) and Sandarupa (2012) defined tongkonan as social aggregation, that is the union of the family group, starting with one grandmother, and agreed by members of those family groups. This union has a rule, which called the rule of cognates family lineage.

Tongkonan orientation is always facing the north as a symbol of respect to Puang Matua. The south part is facing the pollo' banua or puya direction, representing the relation to the ancestors and life after mortality. West and East describe left and right side of the body. East part also symbolizes the relation to the divas (goddess), while West symbolizes the relation to the respected ancestors. Life in the tradition unity within tongkonan (family union) and within the individual is assumed to be the symbol of microcosmos.

Microcosmos classification as the replica of macro cosmos upon East-West, NorthSouth, upper-middle-lower, is assumed to be centered in the tongkonan within the unity of tradition. A whole one family is symbolized by tongkonan centered on the main pillar (ariri posi') and for the individual is centered on the human center. The cosmos classification is manifested into microcosmos like human body and tongkonan. Human is assumed as a symbol of cosmos, that is the human head is assumed as ulunna lino, human lower part as pollo' na lino, right part as matallo and left part as matampu'. Division based on the upper-middle-lower realm is represented in the human body, namely, the head part is assumed as an upper realm, the middle part (abdomen) as the middle realm, and the lower part (legs) as the lower realm.

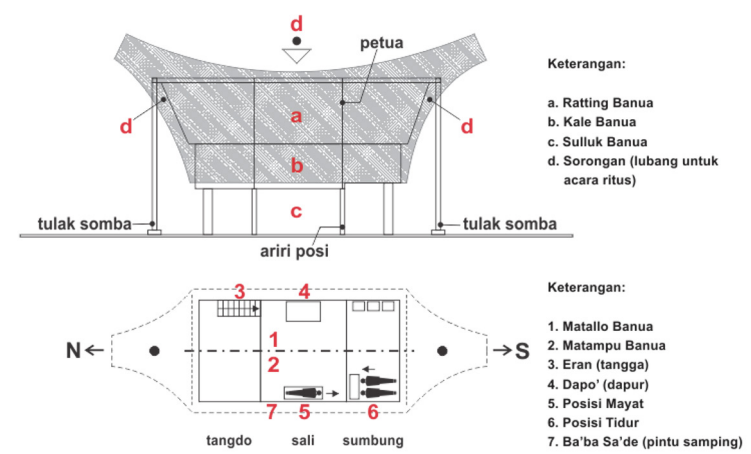

Figure 1: Tongkonan as Microcosmos Source: Lullulangi and Sampebua, 2007

In the wider context, tongkonan represents the center of a village (tondok). Tondok is a traditional area or village of 
certain tradition community which has one form of special traditional, culture and norms. The main components of tondok are: (1) The building consists of tongkonan, alang (food storage) and anakbanua (house); (2) Place for grave (liang); (3) Ceremony areas like rante, penammuan (place for Thanksgiving), pa'buaran (thanks giving's place for public harvest), penanian (place for Thanksgiving and worshipping the banua for one family group); (4) Land of tradition (paddy field and plantation); (5) forest (kombong); (6) farming field (panglambaran); and (7) A well (bubun).

\section{Tondok System Theory}

Tondok system theory was constructed based on the result of unmanteling space layer found at Lembang Sillanan. Space layers at Lembang Sillanan consist of horizontal layers and vertically ranked layers. In the horizontal space, there are four space layers namely: the sacred space around Tongkonan Doa', TangngaTondok space, old and new settlement space. Sacred space in tongkonan Doa' is the tradition communal space which is used to perform a collective ritual for their behalves. Tradition settlement space is a group of tongkonan as a symbol of community collectivity in the form of concession to execute traditional governance. The concession is manifested in the assignment of role and function of tongkonan, either of the tongkonan karua or tongkonan tumpu. Old settlement space is a traditional settlement buffer where the components of the buffer are located. The existence of the components such as rante, bubun, and plantation area represents the support of the buffer. The tongkonan tumpu are mostly located at the old settlement, while the new settlement is the developed settlement at post-independence, where the road access was already opened so that the community could choose to stay in the neighborhood of the developed roads.

From the horizontal space layer, there are several interesting things to notice: firstly, the existence of defending space as the manifestation of the safety needs during the civil war. Secondly, the tongkonan structure is also correlated to the horizontal space layer where the tongkonan karua is located in the traditional settlement while tongkonan tumpu is located in the old settlement. Thirdly, the buffer components of tongkonan are located in the old settlement layer. Fourthly, Buntu
Suriak as polo' na lino becomes the main sign of Sillanan community. Fifthly, it is the road access from matallo (sunset). Those phenomena unity are bound within a unit of settlement system called tondok.

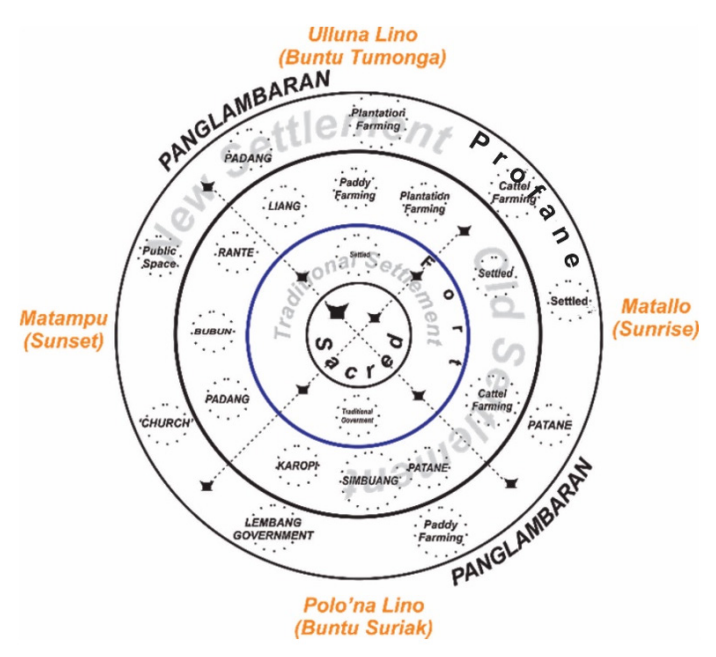

Figure 2, Horizontal Space Layer

Source: Reflection, 2015

Tondok represents the main revelation of physical space where the tongkonan is the main component existing in a tondok. The revelation of the physical space is manifested in various signs like the existence of tongkonan including the supporting components, shifting of area utilization due to the economic demands, and infrastructure development, as well as other signs existing in the physical space. The values that appeared in the horizontal are historical value existing in TangngaTondok, the religious value in the Tongkonan Doa' as a sacred place, manifested an economic value of the old and new settlement, and cultural value of the various acts of Sillanan community.

The unity of space reality was seen in the vertical space. Each level of space represents the revelation result of the above existence. This means that there is the text of context relation between upper and lower level. Penawa (spirit) level represents the manifestation or unfolding one of The Creator's attributes, namely love. Revelation is either individual (madoang or love for the ancestors) or communal (toma'rapu or union). Aluk level represents religious space which becomes knowledge and policy to the Sillanan community. Recently, a transformation/ conversion has occurred from the Aluk Todolo (sangka'sola pamali) to Christianity.

Ada' level represents community 


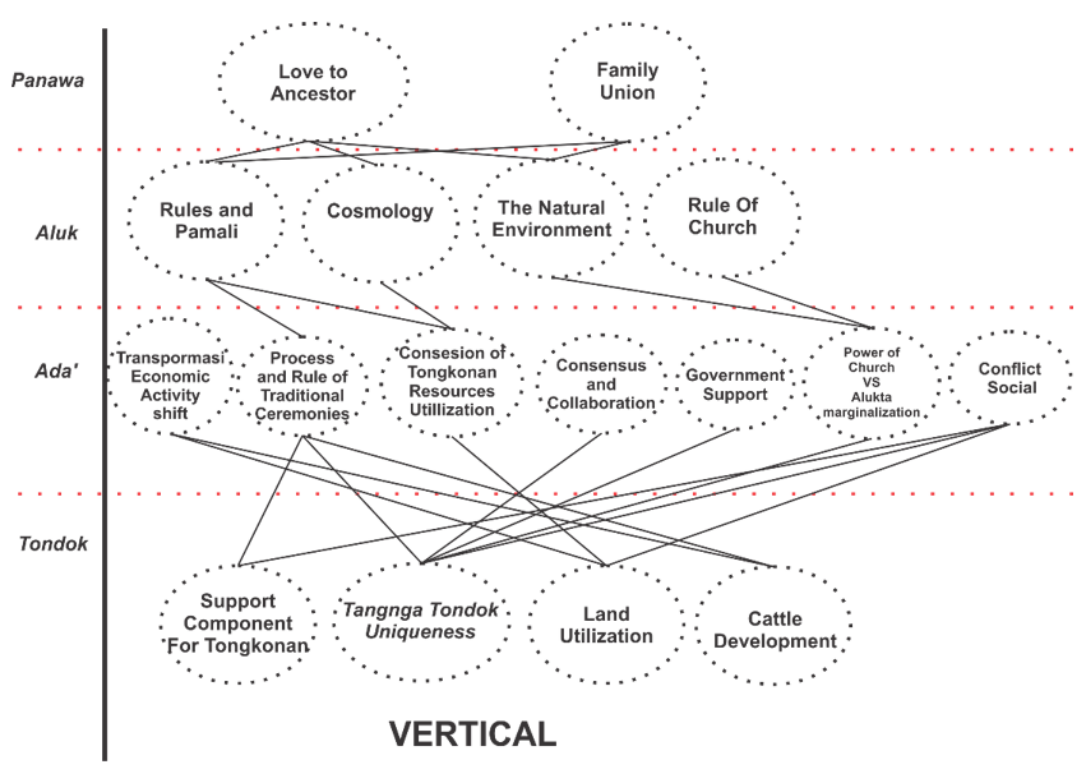

Figure 2. Vertical Space Layers Source: Reflection, 2015

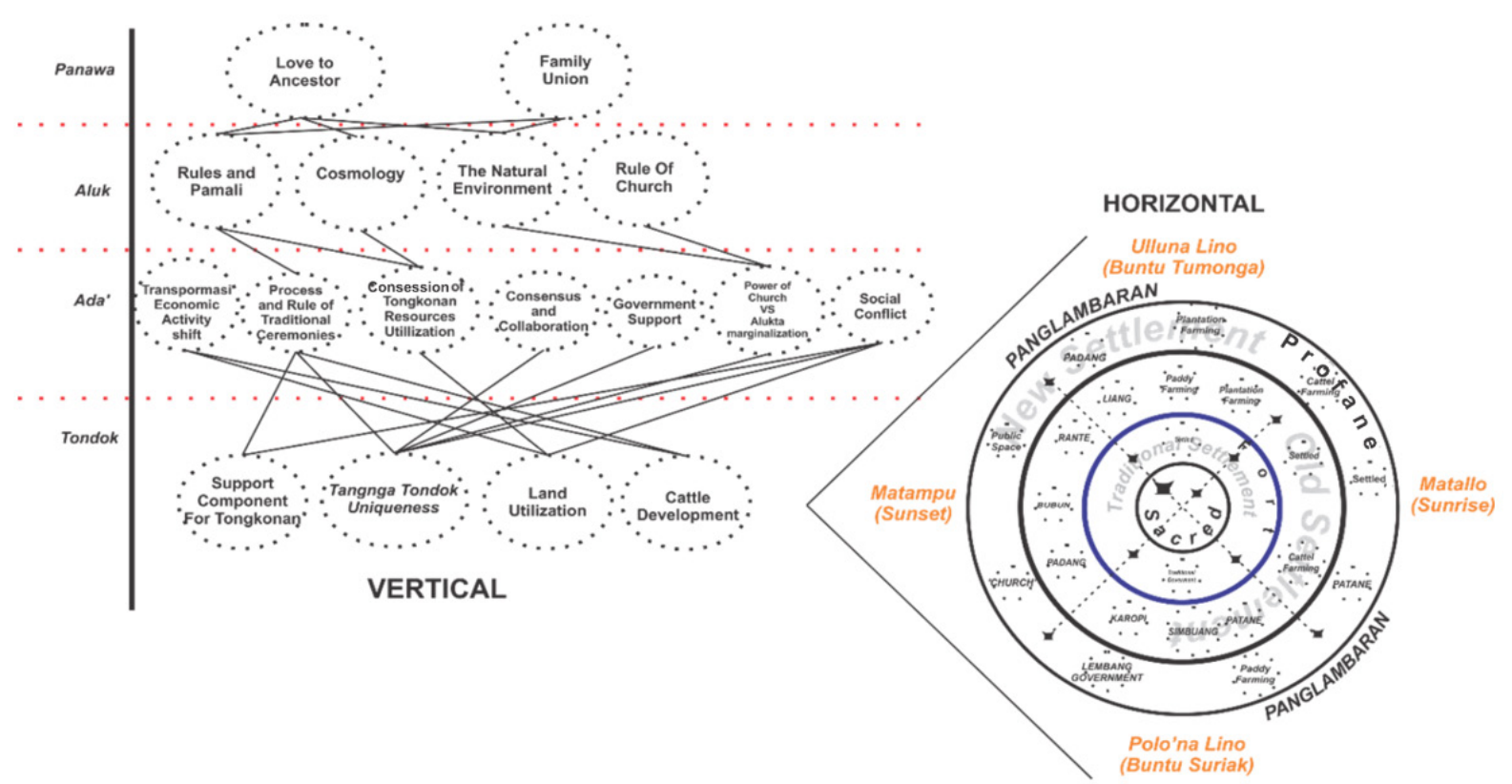

Figure 3. Reality Relation and Existence of Tondok System Source: Reflection, 2016

activity manifestation in culture, economic, social, politics, and institutional. The religious political forces and economic development due to the improvement of infrastructure and social-political conditions have changed the traditional order based on aluk tradition. Various ceremonial activities are mainly the rambu tuka', which considered to be contrary to the Christianity teaching and forbidden to be performed, such as the offerings to the divas or blessing to tongkonan using Alukta tradition. Meanwhile, tondok level is explained at horizontal layers.

When noticing the vertical space order, it is seen that those spaces represent the manifestation of tongkonan realities as the main symbol of tondok system. Ontologically, these realities represent the manifestation of consciousness or spirituality form of Sillanan community. Basically, the spirituality of tondok system is a revelation of transcendental attributes into consciousness space. Each space level represents revelation of transcendental attributes in from of idea, knowledge, activities, up to the physical entities. The diversity of entities within consciousness hierarchy is the evidence of The Creator existence. 


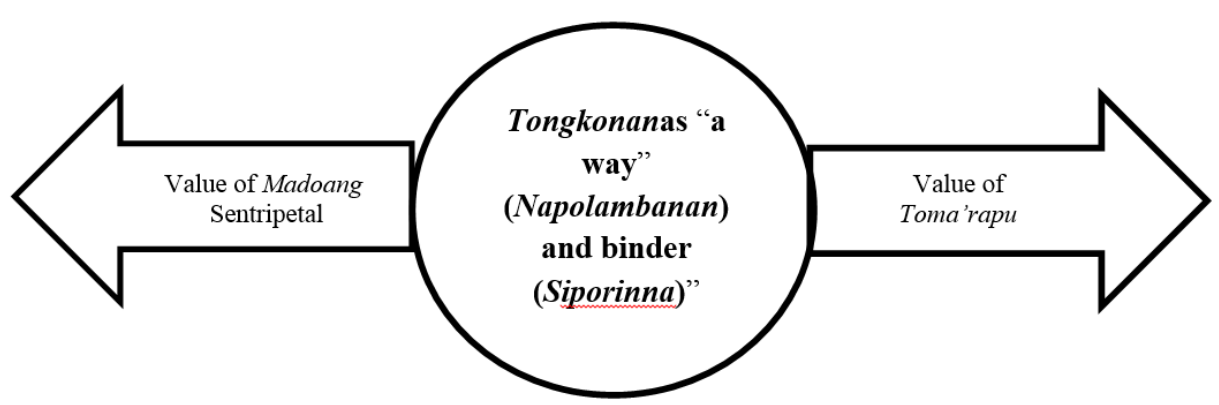

Figure 4. Tongkonan as a Way and Binder

Source: Reflection, 2015

\section{Structure of Tondok System}

Theory of tondok system tries to structurize the consciousness level in form of consciousness level category. This theory is distinct to other previous theories in which the reality structure or consciousness explained. This means that, ontologically, the theory of tondok system is trying to explain the consciousness hierarchy, which represents the manifestation process of "exist" up to the level of "existence" as physical existence. Tongkonan as the main component in tondok represents the symbol of "exist" that can be physically recognized.

Theory of tondok system is not only explaining the reality structure ontologically but also finds the existence of space hierarchy horizontally. This hierarchy is similar to the result of another study in which there are some space layers manifested in the object existence space. Only the symbol and form of consciousness object that distinguishes one layer from another. The main symbol of tondok system is the tongkonan form including the pair (alang) and supporting elements. The process of "to exist" is manifested through local religious knowledge concept (aluk) as well as the cosmology which became the fundamental of tondok layout (settlement) in Lembang Sillanan. The process to exist at a lower level is manifested in various forms of activity such as ceremony, traditional governance rule, the interrelation of groups, etc. Various activities were performed consistently and fully dedicated (commitment) by Sillanan community, and finally, space layers were formed as the form of existence of Sillanan community consciousness.

\section{The Meaning of Tongkonan}

The existence of tongkonan was obtained by involving intentional feeling and emotion in capturing the tongkonan as an object which became an emotional source. The emotion of Sillanan community to the tongkonan was clearly seen in every dialogue that always focusing on every tongkonan existing in TangngaTondok. The true meaning of tongkonan will be revealed when Sillanan community is able to embrace the tongkonan entity within themselves, which then it becomes meaningless in physical appearance. In this form, according to Heidegger (1962), that the authenticity of tongkonan can be seen. Involving emotion and feeling to tongkonan which then getting through the embracing process gave birth to an understanding of how it was related to knowledge system of Sillanan community. The last step to obtain the tongkonan existence was done by interpreting tongkonan nature. Understanding of tongkonan afterward was widened or expanded by local knowledge and meaning or nature of tongkonan was finally interpreted explicitly.

From this Heidegger approach, it could be interpreted that tongkonan represents a way (napolambanan) for a human at Sillanan to come back to The Creator. This way is aimed specially for the ancestors of Sillanan in a family of specific tongkonan. The sacrifices done were based on love for the ancestor within a family union. Love is more inward into each of individual of Sillanan community, while union represents outward value from each individual. Herefrom, tongkonan can be interpreted as a binder (siporinna) of individuals within the big family.

\section{Integrative Transcendental Planning}

From the integrative transcendental view, planning is a process of experiencing, acting, thinking which based on transcendental intuition. Transcendental spirit is the space core which will be manifested into consciousness 
spaces of knowledge, social, and physic. The process of experiencing in the planning is in the physical space, acting process is in the social space, and the intuition is in transcendental space. Physical space needs logical and rational thinking process; social space needs creative and practical thinking process, and knowledge space needs intuitive and associative thinking process.

The idea of integrative transcendental planning was the development of research result (theory of tondok system), the theory of socio-spatial (Rappoport, 1969), social capital theory (Putnam, 2001), and paradigm of wujudiyyah - Ibnu Arabi (Izutsu, 2015). The triadic dialectic of Rapoport (social-spatial-environment) and Putnam (believe-correlation- cooperation) which were fragmented, being transformed using the paradigm of wujudiyyah from Ibnu Arabi into planning form based on consciousness. Consciousness is the existence form (being) that stresses the presence aspect (Palmer, 2001). This consciousness is holarchy (comprehensive reality) as it was explained in the holonomic theory (Palmer, 2001) as well as the theory of everything (Wilber, 2000). Palmer in holonomic divided reality into two big parts namely ontic reality which is the tangible and ontological reality which is intangible.

Integrative transcendental planning is an idea to connect the planning model of instrumental and rational one which is nontheistic or non-spiritual to the transcendental spirit obtained from the exploration. This view is in accordance with Mahzar (1983) opinion that integrative transcendental is the nature of the philosophy of science, considering a return to God. Instrumental and rational planning which work in material and social space is constructed by knowledge and transcendental space within realities of unity.

Substantially, integrative transcendental planning has three characteristics in viewing the planning objects, namely formed by tangible - intangible dimension, considering the exoteric dimension (centrifugal) - esoteric dimension (centripetal) of the planning subject, and formed four quadrants from the integration of its component dimensions. In integrative transcendental planning, the object must be considered from tangible physical (sensed) dimension to nonphysical (unsensed) dimensions. Viewing the subject of planning must also observing its physical and nonphysical elements (soul). This means the whole planning subject consciousness must be able to be considered in the planning process.

From those dimensions, the four quadrants can be formed namely; tangibleexoteric, intangible-exoteric, tangible - esoteric, and intangible esoteric. At tangible - exoteric quadrant, the element needed to consider is physical-network. Physical - network is a physical element of environmental and relation of the social and cultural system, which forms community's activity within planning object. At intangible - esoteric quadrant, the element needed to be considered is local knowledge including the understanding. At tangible esoteric quadrant, the element needed to be considered is the information unit including the symbol found in the object of planning. At the intangible esoteric quadrant, the value element obtained from the intuition must pay attention to the object of planning. When observing the model of integrative transcendental planning, it seems that consciousness substance becomes the observation point of the planning process. Hereby, integrative transcendental planning is also called planning based on the consciousness.

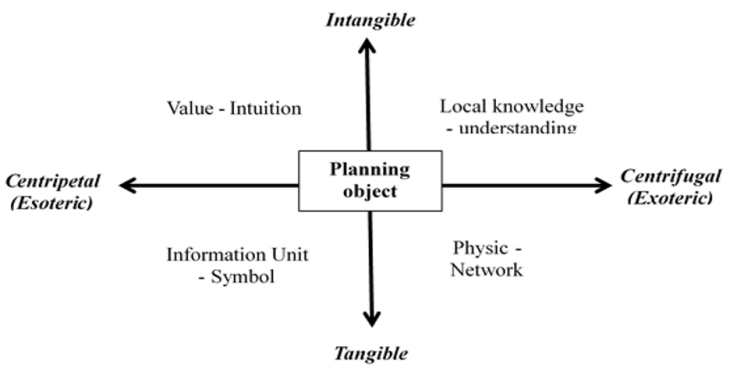

Figure 5. The substance of Planning Based on Consciousness Source: Reflection, 2016

\section{Conclusion}

In Lembang Sillanan community, Tondok represents the main revelation of physical space where the tongkonan is the main component existing in a tondok. The revelation of the physical space is manifested in various signs like the existence of tongkonan including the supporting components, shifting of area utilization due to the economic demands, and infrastructure development, as well as other signs existing in the physical space. Tongkonan represents a way (napolambanan) for human of Sillanan to come back to The Creator. This way is aimed specially for the ancestors of Sillanan in a 
family of specific tongkonan. The sacrifices did base on love for the ancestor within a family union. Love is more inward into each of individual of Sillanan community, while union represents the outward value of each individual. Herefrom tongkonan can be interpreted as a binder (siporinna) of individuals within the big family. Tongkonan represents the center of a village (tondok). Tondok is a traditional area or village of certain tradition community which has one form of special traditional, culture and norms. Tondok system theory was constructed based on the result of unmanteling space layer found at Lembang Sillanan. Space layers at Lembang Sillanan consist of horizontal layers and vertically ranked layers. In the horizontal space, there are four space layers namely: the sacred space around tongkonan Doa', Tangnga Tondok space, old and new settlement space. Sacred space in tongkonan Doa' is the customary communal space which is used to perform a collective ritual for their behalves. Customary settlement space is a group of tongkonan as a symbol of community collectivity in the form of concession to execute traditional governance. The concession is manifested in the assignment of role and function of tongkonan, either of the tongkonan karua or tongkonan tumpu. Old settlement space is a customary settlement buffer where the components of the buffer are located. The existence of the components such as rante,bubun, and plantation area represents the support of the buffer. The tongkonantumpu are mostly located at the old settlement, while the new settlement is the developed settlement at post-independence, where the road access was already opened so that the community could choose to stay in the neighborhood of the developed roads.

The unity of space reality was seen in the vertical space. Each level of space represents the revelation result of the there above existence. This means that there is the text of context relation between upper and lower level. Penawa (spirit) level represents the manifestation or unfolding of one of The Creator attributes, namely love. Revelation is either individual (madoang or love to the ancestors) or communal (toma 'rapu or union). Aluk level represents religious space which becomes knowledge and policy to the Sillanan community. Recently, the transformation has occurred from the Aluk Todolo sangka' sola pamali) to the Christianity. Those spaces represent the manifestation of tongkonan realities as the main symbol of tondok system. Ontologically, these realities represent the manifestation of consciousness or spirituality form of Sillanan community. The theory of tondok system is trying to explain the consciousness hierarchy, which represents the manifestation process of "exist" up to the level of "existence" as physical existence. Tongkonan as the main component in a tondok represents the symbol of "exist" that can be physically recognized. From the Heidegger approach, it could be interpreted that tongkonan represents a way (napolambanan) for human of Sillanan to come back to The Creator. This way is aimed specially for the ancestors of Sillanan in a family of specific tongkonan.

Integrative transcendental planning is an idea to connect the planning model of instrumental and rational one which is nontheistic or non-spiritual to the transcendent spirit obtained from the exploration. From the integrative transcendental view, planning is a process of experiencing, acting, thinking which based on transcendental intuition. Transcendental spirit is the space core which will be manifested into consciousness spaces there below, namely space of knowledge, social, and physic. Substantially, integrative transcendental planning has three characteristics in viewing the planning objects, namely formed by tangible intangible dimension, considering the exoteric dimension (centrifugal) - esoteric dimension (centripetal) of the planning subject, and formed four quadrants from the integration of its component dimensions. In integrative transcendental planning, the object must be considered too from tangible physical (sensed) dimension to nonphysical (unsensed) dimensions. View to the subject of planning also must be observing the physical and nonphysical elements (soul). This means the whole planning subject consciousness must be able to to be considered in the planning process.

\section{References}

Adian, D. G. (2010). Pengantar Fenomenologi. Penerbit Koekoesan. Depok.

Allmendinger, P. (2001). Planning in Postmodern Times. Routledge. London.

Beauregard, R. (1984). Between Modernity and Postmodernity: The Ambiguous Position of U.S. Planning. Blackwell Publisers Inc. Massachusetts

Bigalke, T. W. (2005). Tana Toraja: A Social History of an Indonesian People. KILTV 
Press. Leiden.

Campbell, S., Fainstein, S.S. (1996). Readings in Planning Theory. Blackwell Publisher. Massachusetts.

Faludi, A. (1973). Planning Theory. Pergamin. London.

Findlay, J. N. (1970). Logical Investigation (translate). Routledge and Kegan Paul. London

Forester, J. (1989). Planning In The Face of Power. University of California Press. Berkeley.

Friedman, J. (1987). Planning in the Public Domain from Knowledge to Action. Princeton University Press. New Jersey.

Habermas. (1984). The Theory of Communicative Action. Beacon Press. Boston.

Healey, P. (1997). Collaborative Planning, shaping places in fragmented societies. MacMillan Press. London.

Heidegger, M, (1962). Being and Time: A Translation of Sein and Zeit, terjemahan J. Macquarrie \& E. Robinson, Harper \& Row. New York.

Innes, J.E. (1994). Planning Through Consensus-Building, a new view of the comprehensive planning ideal, IURD Working Paper 626, University of California. Berkeley.

Izutsu, T. (2015). Sufisme. Mizan. Bandung. Kobong, T. (2008). Injil dan Tongkonan (Inkarnasi, Kontekstualisasi dan
Transformasi). BPK Gunung Mulia. Jakarta.

Lullulangi, M. dan Sampebua, O. (2007). Arsitektur Tradisional Toraja. Badan Penerbit Universitas Negeri Makassar, Makassar-Sulawesi Selatan.

Mahzar, A. (1983). Integralisme Sebuah Rekonstruksi Filsafat Islam. Pustaka Salman. Bandung

Moustakas, C. (1994). Phenomenological Research Methods. Sage Publications. London

Palmer, K.D. (2001). Holonomic Theory of Consciousness. http://archonic.net

Putnam, (2001). Bowling Alone: The Collapse and Revival of American Community. Simon and Schuster. New York

Rappoport, A. (1969). Human Aspect of Urban Form. Pergamon Press Ltd. Oxford

Sager, T. (1994). Communicative Planning Theory. Aldeshot. Avebury.

Sandarupa, S. (2012). Life and Death in Toraja. PT. Torindo (Toraja-Indonesia) Makassar Sulawesi Selatan.

Setriyanto. (2013). Sekilas Profil Tongkonan Tua Sillanan. Makale Sulawesi Selatan.

Sudaryono, (2012). Fenomenologi Sebagai Epistemology Baru Dalam Perencanaan Kota dan Permukiman. Universitas Gadjah Mada. Yogyakarta

Wilber, K. (2000). A Theory of Everything: An Integral Vision for Business, Politics, Science and Spirituality. Shambhala Publication. Boston. 